\title{
The anti-inflammatory effects of cinnamyl alcohol on sepsis-induced mice via the NLRP3 inflammasome pathway
}

\author{
Laiyu Zou, Chen Li, Xiaoling Chen, Feng Yu, Qian Huang, Linjun Chen, Wenwei Wu, Qing Liu \\ Department of Infectious Disease, Fujian Medical University Union Hospital, Fuzhou, China \\ Contributions: (I) Conception and design: L Zou; (II) Administrative support: L Zou; (III) Provision of study materials or patients: C Li, X Chen; (IV) \\ Collection and assembly of data: F Yu, W Wu; (V) Data analysis and interpretation: W Wu, Q Liu; (VI) Manuscript writing: All authors; (VII) Final \\ approval of manuscript: All authors. \\ Correspondence to: Laiyu Zou. Department of Infectious Disease, Fujian Medical University Union Hospital, Fuzhou 350001, China. \\ Email: bszly@163.com.
}

\begin{abstract}
Background: Sepsis is an excessive inflammatory response to an infection that fails to return to homeostasis. It occurs frequently in patients following a primary infection or injury and is one of the most common causes of mortality in hospitalized patients. However, there is currently no specific and effective therapy for the management of sepsis. Previous findings have suggested that cinnamon and cinnamon extracts have anti-inflammatory and anti-oxidative activities and therefore, may be effective in treating sepsis. Methods: In the present study, Escherichia coli was injected into mice to induce sepsis. Hematoxylin and eosin staining was used to investigate the influence of cinnamyl alcohol on histological changes including heart, liver, lung, and kidney tissues. Western blotting and real-time polymerase chain reaction (RT-PCR) were applied to measure the levels of NLRP3 inflammasome. The levels of interleukin (IL)-1 $\beta$ and IL-18 in the serum were detected with enzyme-linked immunosorbent assay (ELISA) method.
\end{abstract}

Results: Administration of cinnamyl alcohol by gavage effectively reduced the mortality of septic mice (70\% survival), compared to untreated septic mice (50\% survival). The histological findings indicated that cinnamyl alcohol reduced the inflammatory reaction in the liver, heart, lungs, and kidneys of the septic mice. In the circulatory system, the concentrations of the inflammatory cytokines IL-1 $\beta$ and IL-18 were significantly decreased by cinnamyl alcohol administration compared to the untreated septic group. Western blot analysis and quantitative polymerase chain reaction (qPCR) demonstrated that cinnamyl alcohol decreased the expression of apoptosis-associated speck-like protein containing a C-terminal caspase recruitment domain (ASC), nucleotide-binding oligomerization domain-like receptor 3 (NLRP3), and caspase-1 in the liver, heart, lungs, and kidneys of the mice, suggesting that cinnamyl alcohol alleviated sepsis syndrome via the NLRP3 inflammasome pathway.

Conclusions: Cinnamyl alcohol may be a novel therapeutic candidate for the treatment of sepsis syndrome.

Keywords: Sepsis; inflammatory; cinnamyl alcohol; cinnamon; NLRP3 inflammasome pathway

Submitted Oct 26, 2021. Accepted for publication Jan 13, 2022.

doi: 10.21037/atm-21-6130

View this article at: https://dx.doi.org/10.21037/atm-21-6130

\section{Introduction}

Sepsis is described as an excessive inflammatory response to an infection that fails to return to homeostasis (1). Sepsis syndrome frequently occurs in patients following an infection and/or injury and has become one of the most common causes of death in hospitalized patients worldwide $(2,3)$. The dysregulated inflammatory response is caused by heterogeneous microbial pathogens, predominantly gramnegative bacteria (4). Sepsis shack occurs when there is lifethreatening organ failure, including cardiovascular, renal, 
hepatic, and neurological dysfunction $(5,6)$, and is associated with high morbidity and mortality (7). However, to date, there is still no specific medicine nor effective therapy for the treatment of patients with sepsis syndrome. Advances in the understanding of the pathological mechanisms involved in sepsis has revealed that the inflammatory syndrome predominantly involves a dysfunction of the host innate immune system (8).

The inflammatory reaction is essential to inform the host immune system of the presence of an infection. After an infection, the host response is primarily activated by pathogen associated molecular patterns (PAMPs) that include toxins, endotoxins, and protein particles from invading pathogens, which is mediated by pattern recognition receptors (PPRs) (9). The recognition in immune cells leads to an increased release of cytokines including tumor necrosis factor (TNF), interleukin-1 (IL1), interleukin-6 (IL-6), and high-mobility group box1 protein (HMGB-1), as well as non-cytokine mediators such as macrophage migratory inhibitory factor (MIF), platelet activating factor (PAF), nitric oxide (NO), complements, and eicosanoids (10). PPRs also recognize damage-associated molecular patterns (DAMPs) that include various damaged proteins and organelle contents released from injured cells, and this also contributes to the release of various pro-inflammatory mediators $(11,12)$. The inflammatory response is typically balanced with inflammation resolution. However, in the sepsis patient, this homeostasis is disturbed. Activation of the NLRP3 inflammasome is necessary for adaptive immune responses and innate immune defense. In addition, NLRP3 inflammasome has been proved to be closely involved in the occurrence and evolution of sepsis (13).

Cinnamon is a traditional Chinese medicine and has been used for thousands of years. Cinnamon and cinnamon extracts have been demonstrated to have anti-inflammatory and anti-oxidative activities (14). However, it is unclear whether cinnamon or cinnamon extracts are effective at reducing sepsis syndrome. The present study investigated the potential application of a cinnamon extract, cinnamyl alcohol, in sepsis therapy. The specific objectives were as follows: (I) to confirm the effects of cinnamyl alcohol on the mortality of septic mice; (II) to determine the effects of cinnamyl alcohol on the secretion of inflammatory cytokines in the circulatory system; and (III) to demonstrate the effects of cinnamyl alcohol on the production of inflammatory cytokines in multiple organs. Previous report has indicated that the anti-inflammatory effects of cinnamyl alcohol (15). However, we firstly demonstrated the anti-inflammatory effects of cinnamyl alcohol in the sepsis animal model, and the anti-inflammatory roles were achieved through NLRP3 inflammasome pathway.

We present the following article in accordance with the ARRIVE reporting checklist (available at https://atm. amegroups.com/article/view/10.21037/atm-21-6130/rc).

\section{Methods}

\section{Animals}

A total of 40 specific pathogen free male C57BL/6J mice (8-10 weeks old) were purchased from Shanghai Lingchang Biological Technology Co., Ltd. (Shanghai, China) and housed in an animal facility under a 12-hour light-dark cycle, in an ambient temperature of $22-25^{\circ} \mathrm{C}$ and humidity of $50 \%$. The mice were given free access to food and water. After a week of acclimatization, the mice were randomly divided into four groups. In the control group, the mice were given phosphate buffered saline (PBS) by gavage and injection of PBS. In the model group, mice were administered PBS by gavage and sepsis was induced by injection of Escherichia coli. In the cinnamyl alcohol group (CA group), mice were treated with cinnamyl alcohol $(2 \mathrm{~g} / \mathrm{kg})$ by gavage and injected with PBS. In the model + CA group, mice were given cinnamyl alcohol $(2 \mathrm{~g} / \mathrm{kg})$ by gavage and sepsis was induced by injection of $E$. coli. Animal experiments were granted by the ethics committee of Fujian Medical University (No. FJMU IACUC 20210512) and conformed to the Guide for the Care and Use of Laboratory Animals of the National Institute of Health for the care and use of animals. During the experimental period, all efforts were made to minimize animal suffering. The dose of cinnamyl alcohol was determined based on our pre-experiment and previous reports $(16,17)$. The cinnamyl alcohol was purchased from MedChemExpress (Shanghai, China), and prepared with ethanol.

\section{Induction of sepsis}

The E. coli strain (ATCC 25922) of bacteria was inoculated into $100 \mathrm{~mL}$ Luria-Bertani broth and cultured overnight at $37^{\circ} \mathrm{C}$ with shaking. The bacteria were washed, resuspended in sterile PBS, and serially diluted to achieve $10^{9}$ colonyforming units $(\mathrm{CFU}) / \mathrm{mL}$. Prior to injection, mice were anesthetized with $1 \%$ pentobarbital sodium $(80 \mathrm{mg} / \mathrm{kg}$ body weight). The E. coli solution was administered 
Table 1 Primers used in the present study

\begin{tabular}{lll}
\hline Gene & Forward primer (5'-3') & Reverse primer (5'-3') \\
\hline NLRP3 & ATTACCCGCCCGAGAAAGG & TCGCAGCAAAGATCCACACAG \\
ASC & GCTACTATCTGGAGTCGTATGGC & GACCCTGGCAATGAGTGCTT \\
Caspase-1 & ACTGACTGGGACCCTCAAGT & GCAAGACGTGTACGAGTGGT \\
GAPDH & ATCAACGGGAAACCCATC & GAAGACGCCAGTAGACTCCA \\
\hline
\end{tabular}

NLRP3, nucleotide-binding oligomerization domain-like receptor 3; ASC, apoptosis-associated speck-like protein containing a caspase recruitment domain; GAPDH, glyceraldehyde 3-phosphate dehydrogenase.

intravenously into the tail vein of the mice to induce sepsis syndrome. Intragastric administration of the cinnamon extract $(250 \mathrm{mg} / \mathrm{kg})$ was performed 1 hour before $E$. coli injection. Animals were observed at 6 hours intervals and the mortality rate was recorded.

\section{Sampling and histological analysis}

Blood samples were drawn from the tail vein of the mice 48 hours after treatment and centrifuged for 10 minutes at $3,000 \times \mathrm{g}$ to obtain the plasma. Subsequently, the mice were sacrificed with a lethal dose of pentobarbital and the liver, heart, lungs, and kidneys were harvested. Tissue samples were immediately frozen in liquid nitrogen and stored at $-80{ }^{\circ} \mathrm{C}$ until further analyses. The organ samples were fixed with $10 \%$ formalin for 48 hours and embedded in paraffin. Slides containing the paraffin-embedded sections $(10 \mu \mathrm{m})$ were deparaffinization and dyed using hematoxylin and eosin. The slides were observed with an Olympus microscope (BX50 model).

\section{Quantitative real-time polymerase chain reaction ( $q R T$ - PCR)}

Apoptosis-associated speck-like protein containing a caspase recruitment domain (ASC) and nucleotide-binding oligomerization domain-like receptor 3 (NLRP3) were selected for gene expression quantification using relative real-time PCR. Total RNA was extracted from the liver, heart, lungs, and kidney using TRIzol reagent (Invitrogen, CA, USA) according to the manufacturer's instructions. The concentration and integrity of the RNA was measured using NanoDrop (ND-1000) and Agilent Bioanalyzer 2100 (Agilent Technologies). cDNA was synthesized using Evo M-MLV RT Kit with gDNA Clean for qPCR II (Accurate Biotechnology Co., Ltd., Hunan, China). qRT-PCR was performed on a QuantStudio 3 Real-time PCR System
(Thermo Scientific, MA, USA) using TB Green Premix Ex TaqTM II (Takara, Dalian, China) Kit according to the manufacturer's instructions. The qRT-PCR program was as follows: denaturation at $95^{\circ} \mathrm{C}$ for 30 seconds, followed by 40 cycles of denaturation at $95^{\circ} \mathrm{C}$ for 5 seconds, and annealing and extension at $60{ }^{\circ} \mathrm{C}$ for 30 seconds. The dissociation curve of the amplification products was analyzed to confirm that only one PCR product was amplified and detected. The data were calculated using the $2^{-\Delta \Delta \mathrm{Ct}}$ method (Livak and Schmittgen 2001). The PCR primers used are provided in Table 1.

\section{Enzyme-linked immunosorbent assay (ELISA) and Western blot analysis}

The plasma concentrations of interleukin (IL)- $1 \beta$ and IL18 were determined using ELISA kits according to the manufacturer's protocols. The expression levels of ASC, NLRP3, and caspase-1 were measured using Western blot. Tissue samples were homogenized with sample buffer (50 mM Tris-HCl, pH 7.4, $150 \mathrm{mM} \mathrm{NaCl,1 \%} \mathrm{NP-40,}$ $0.1 \%$ SDS, $10 \mu \mathrm{L}$ proteinase inhibitor). After centrifugation for 20 minutes at $12,000 \mathrm{rpm}$ at $4{ }^{\circ} \mathrm{C}$, the supernatant was collected and protein concentration was determined using the BCA Protein Assay Kit (Abcam). The proteins were separated by $12 \%$ sodium dodecyl sulphate-polyacrylamide gel electrophoresis (SDS-PAGE) and transferred onto polyvinylidene difluoride (PVDF) membranes (Millipore Co., Billerica, MA, USA). The membranes were blocked with $5 \%$ nonfat milk and for 1 hour at room temperature followed by incubation with primary antibodies (1:1,000 dilution) overnight. Membranes were washed 3 times with PBST (PBS with $0.05 \%$ Tween 20) followed by incubation with a horseradish peroxidase-conjugated goat-antirabbit antibody (1:20,000 dilution) for 1 hour at room temperature. After 3 washes with PBST, the band intensities were analyzed using the Image Lab software (Bio-Rad) 
Table 2 The mortality of mice in during the 48 hours post-administration

\begin{tabular}{lcccccccccc}
\hline \multirow{2}{*}{ Group } & \multicolumn{1}{c}{ Number of survivals } & & \\
\cline { 2 - 9 } & $0 \mathrm{~h}$ & $6 \mathrm{~h}$ & $12 \mathrm{~h}$ & $18 \mathrm{~h}$ & $24 \mathrm{~h}$ & $30 \mathrm{~h}$ & $36 \mathrm{~h}$ & $42 \mathrm{~h}$ & $48 \mathrm{~h}$ \\
\hline Control & 10 & 10 & 10 & 10 & 10 & 10 & 10 & 10 & 10 & $100 \%$ \\
Model & 10 & 9 & 9 & 8 & 6 & 6 & 6 & 5 & 5 & $50 \%$ \\
CA & 10 & 10 & 10 & 10 & 10 & 10 & 10 & 10 & 10 & $100 \%$ \\
Model + CA & 10 & 8 & 8 & 7 & 7 & 7 & 7 & 7 & 7 & $70 \%$ \\
\hline
\end{tabular}

CA, cinnamyl alcohol.

and quantified using the Image $\mathrm{J}$ analysis software. The antibodies used in this study were listed as follows: rabbit monoclonal to ASC (\#ab283684, Abcam, UK), rabbit monoclonal to NLRP3 (\#ab263899, Abcam, UK), rabbit monoclonal to Cleaved Caspase-3 (\#ab32042, Abcam, UK), goat polyclonal secondary antibody to rabbit IgG (\#ab150077, Abcam, UK).

\section{Statistical analysis}

One-way analysis of variance (ANOVA) was used to compare the data among groups, followed by Turkey posthoc test for multiple comparisons. Prior to the ANOVA test, the normality of data was verified by the ShapiroWilk test. A P value $<0.05$ was considered statistically significant. All statistical analyses were conducted using Graph Pad Prism 5.0 software (San Diego, CA, USA).

\section{Results}

\section{Cinnamyl alcohol increased the survival rate of sepsis mice}

The mortality rate differed among the 4 treatment groups. In mice that were not subjected to sepsis induction, that is, the control group and the CA group, no deaths were recorded during the 48 hours post-administration (Table 2). In the sepsis model group, administration of $E$. coli results in $50 \%(5 / 10)$ mortality. One death was recorded at 6,18 , and 42 hours post-administration, and 2 deaths were observed at 24 hours post-treatment. In mice given cinnamyl alcohol before the induction of sepsis, that is, the model + CA group, a total of 3 mice died, 2 of which occurred at 6 hours post-administration, and 1 occurred at 18 hours postadministration. These findings suggested that cinnamyl alcohol effectively reduced mortality in septic mice. Cinnamyl alcohol may be a novel therapeutic candidate for the treatment of sepsis syndrome.

\section{Cinnamyl alcohol improved the tissues injury of sepsis mice}

The liver, heart, lungs, and kidneys from mice in the control group and the CA group showed normal morphology (Figure 1), suggesting that cinnamyl alcohol did not exert any side effects on these organs. In the sepsis model group, obvious inflammatory cell infiltration, cell necrosis, and tissue abscesses were observed in the liver, heart, lungs, and kidneys (Figure 1). These histopathological changes are consistent with previous findings (18). Among these tissues, the inflammatory reaction was more pronounced in the liver compared to that observed in the heart, lungs, and kidneys (Figure 1). However, inflammatory cell infiltration, cell necrosis, and tissue abscesses were notably inhibited in mice in the model + CA group compared to mice in the model group. In fact, the findings were comparable to that observed in the control group and the CA group (Figure 1). These results indicated that cinnamyl alcohol effectively protected the liver, heart, lungs, and kidneys from excessive inflammatory reactions.

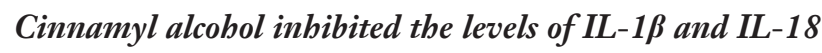 in the serum}

The plasma concentrations of IL-1 $\beta$ and IL-18 were significantly different among the various groups $(\mathrm{F}=549.80$, $\mathrm{P}<0.0001$ for IL-1 $\beta ; \mathrm{F}=924.90, \mathrm{P}<0.0001$ for IL-18). The plasma concentrations of IL-1 $\beta(169.20 \pm 1.92 \mathrm{pg} / \mathrm{mL})$ and IL-18 $(216.50 \pm 3.50 \mathrm{pg} / \mathrm{mL})$ were significantly higher in the model group compared to that in the model + CA group $(120.90 \pm 4.120 \mathrm{pg} / \mathrm{mL}$ for IL- $1 \beta ; 172.50 \pm 3.93$ for IL$18 \mathrm{pg} / \mathrm{mL}$ ) (Figure 2). The plasma concentrations of IL$1 \beta$ and IL-18 were significantly higher in the model + CA group compared to control mice $(94.81 \pm 2.55 \mathrm{pg} / \mathrm{mL}$ for IL- $1 \beta ; 100.20 \pm 2.27 \mathrm{pg} / \mathrm{mL}$ for IL-18) and mice in the CA group $(93.60 \pm 0.42 \mathrm{pg} / \mathrm{mL}$ for IL- $1 \beta ; 172.50 \pm 3.93 \mathrm{pg} / \mathrm{mL}$ for IL-18). No significant differences were observed in 


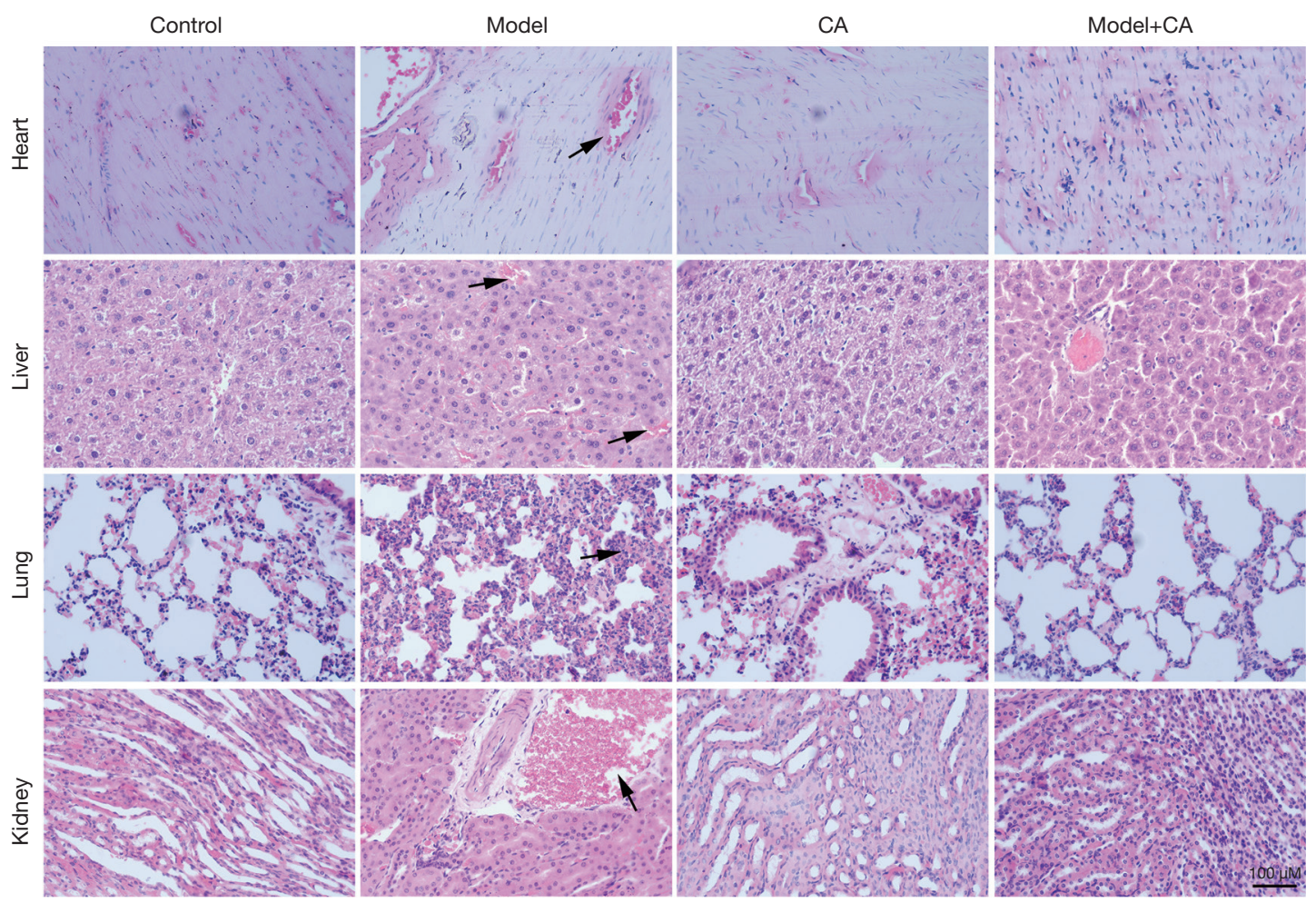

Figure 1 The hematoxylin and eosin staining (magnification $\times 200$ ) and histological analysis of the heart, liver, kidneys, and lungs from mice in the control group, the CA group, the model group, and the model + CA group. Arrows indicate infiltration of inflammatory cells. CA, cinnamyl alcohol.
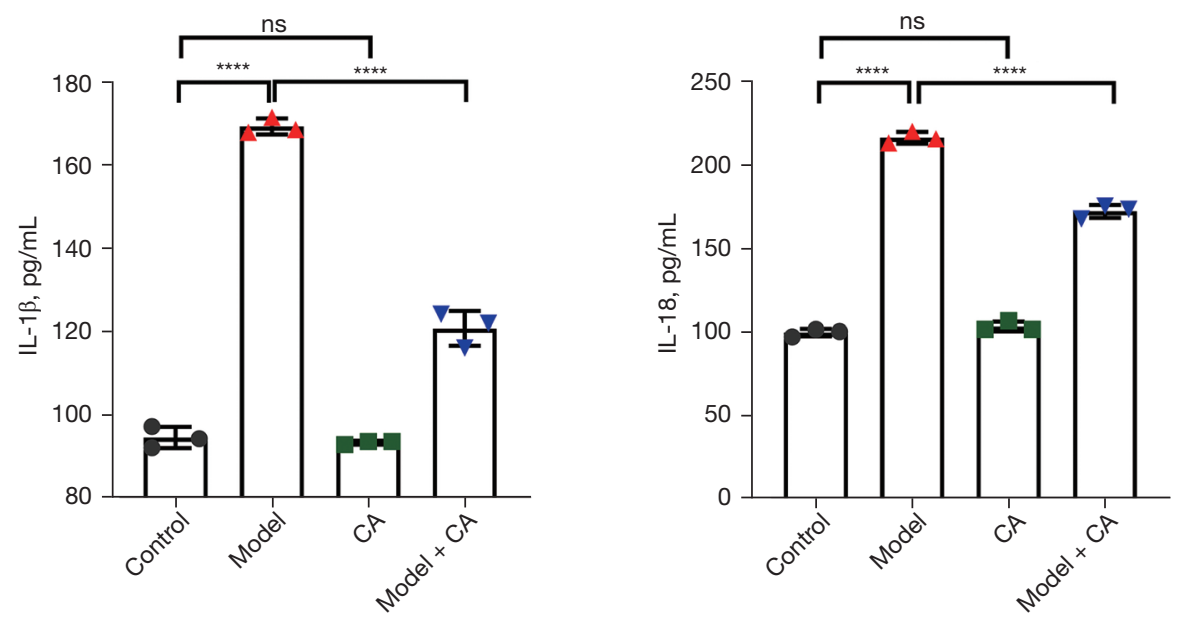

Figure 2 The expression level of IL-1 $\beta$ and IL-18 in the serum of mice. ${ }^{* * * *}, \mathrm{P}<0.0001$. ns, not significant; IL, interleukin; CA, cinnamyl alcohol.

the plasma concentrations of IL- $1 \beta$ and IL-18 between the control group and the CA group. In agreement with previous studies (14), these findings demonstrated the anti- inflammatory activity of cinnamyl alcohol and may indicate that cinnamyl alcohol can alleviate sepsis syndrome by reducing the inflammatory response. 

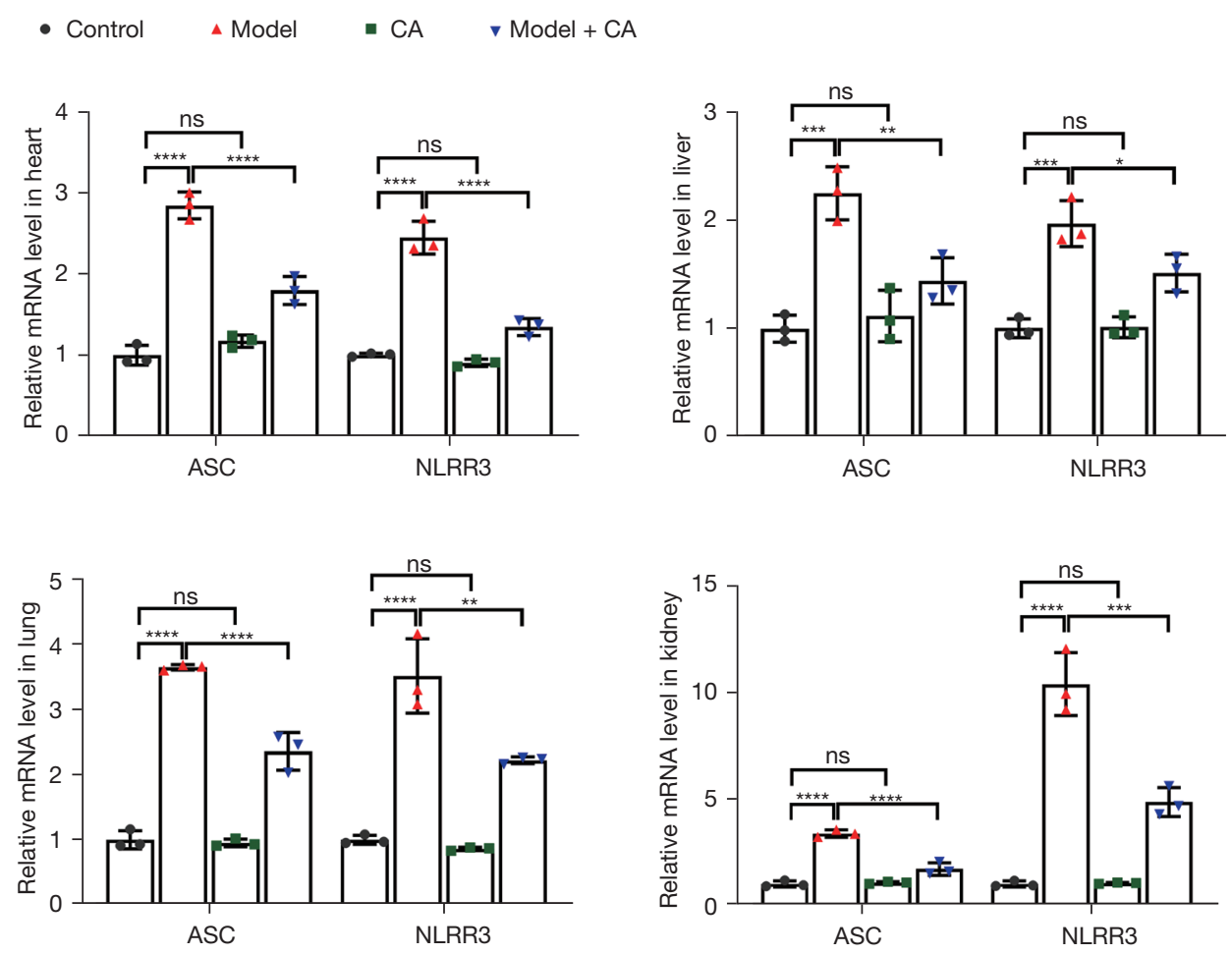

Figure 3 The relative mRNA expression of ASC and NLRP3 in the heart, liver, lungs, and kidneys. ${ }^{* * *}, \mathrm{P}<0.0001{ }^{* * *}, \mathrm{P}<0.001 ;{ }^{* *}, \mathrm{P}<0.01$; *, $\mathrm{P}<0.05$. Error bars, \pm SD. ns, not significant; CA, cinnamyl alcohol; ASC, apoptosis-associated speck-like protein containing a caspase recruitment domain; NLRP3, nucleotide-binding oligomerization domain-like receptor 3.

\section{Cinnamyl alcobol inbibited the $m R N A$ levels of ASC and NLRP3}

The relative mRNA expression of ASC $(\mathrm{F}=21.37, \mathrm{P}<0.001$ for liver; $\mathrm{F}=108.30, \mathrm{P}<0.0001$ for heart; $\mathrm{F}=182.60, \mathrm{P}<0.0001$ for lungs; and $\mathrm{F}=103.00, \mathrm{P}<0.0001$ for kidneys) and NLRP3 $(\mathrm{F}=27.97, \mathrm{P}<0.0001$ for liver; $\mathrm{F}=109.80, \mathrm{P}<0.0001$ for heart; $\mathrm{F}=55.03, \mathrm{P}<0.0001$ for lungs; and $\mathrm{F}=88.00, \mathrm{P}<0.0001$ for kidneys) were significantly different among groups, and the patterns of variation were similar in the liver, heart, lungs, and kidneys (Figure 3). The relative mRNA expression of ASC and NLRP3 was significantly greater in the model group $(2.25 \pm 0.25$ for ASC and $1.97 \pm 0.21$ for NLRP3 in liver; $2.84 \pm 0.17$ for ASC and $2.45 \pm 0.02$ for NLRP3 in heart; $3.65 \pm 0.04$ for ASC and 3.51 \pm 0.57 for NLRP3 in lungs; $3.37 \pm 0.18$ for ASC and $10.40 \pm 1.48$ for NLRP3 in kidneys) compared to the model + CA group (mean \pm SD $=1.44 \pm 0.21$ for $\mathrm{ASC}$ and mean $\pm \mathrm{SD}=1.51 \pm 0.17$ for NLRP3 in liver, mean $\pm \mathrm{SD}=1.80 \pm 0.17$ for ASC and mean $\pm \mathrm{SD}$ $=1.35 \pm 0.10$ for NLRP3 in heart, mean $\pm \mathrm{SD}=2.36 \pm 0.29$ for ASC and mean $\pm \mathrm{SD}=2.22 \pm 0.05$ for NLRP3 in lung, mean $\pm \mathrm{SD}=1.70 \pm 0.30$ for ASC and mean $\pm \mathrm{SD}=4.85 \pm 0.68$ for NLRP3 in kidney). The relative mRNA levels of ASC and NLRP3 were significantly greater in the model + CA group compared to those in the control group (mean $\pm \mathrm{SD}$ $=1.00 \pm 0.13$ for ASC and mean $\pm S D=1.00 \pm 0.09$ for NLRP3 in liver, mean $\pm \mathrm{SD}=1.00 \pm 0.12$ for ASC and mean $\pm \mathrm{SD}$ $=1.00 \pm 0.02$ for NLRP3 in heart, mean $\pm \mathrm{SD}=1.00 \pm 0.14$ for ASC and mean \pm SD $=1.00 \pm 0.07$ for NLRP3 in lung, mean $\pm \mathrm{SD}=1.00 \pm 0.15$ for ASC and mean $\pm \mathrm{SD}=1.00 \pm 0.13$ for NLRP3 in kidney) and the CA group (mean \pm SD $=1.11 \pm 0.24$ for ASC and mean $\pm \mathrm{SD}=1.01 \pm 0.10$ for NLRP3 in liver, mean $\pm \mathrm{SD}=1.17 \pm 0.08$ for ASC and mean $\pm \mathrm{SD}$ $=0.91 \pm 0.05$ for NLRP3 in heart, mean $\pm \mathrm{SD}=0.95 \pm 0.06$ for ASC and mean $\pm \mathrm{SD}=0.86 \pm 0.03$ for NLRP3 in lung, mean $\pm \mathrm{SD}=1.06 \pm 0.06$ for ASC and mean $\pm \mathrm{SD}=1.04 \pm 0.04$ for NLRP3 in kidney). No significant differences were observed between the control group and the CA group.

\section{Cinnamyl alcohol inbibited the protein levels of ASC, NLRP3, and caspase-1}

The relative protein expression of ASC $(\mathrm{F}=87.62, \mathrm{P}<0.0001$ 

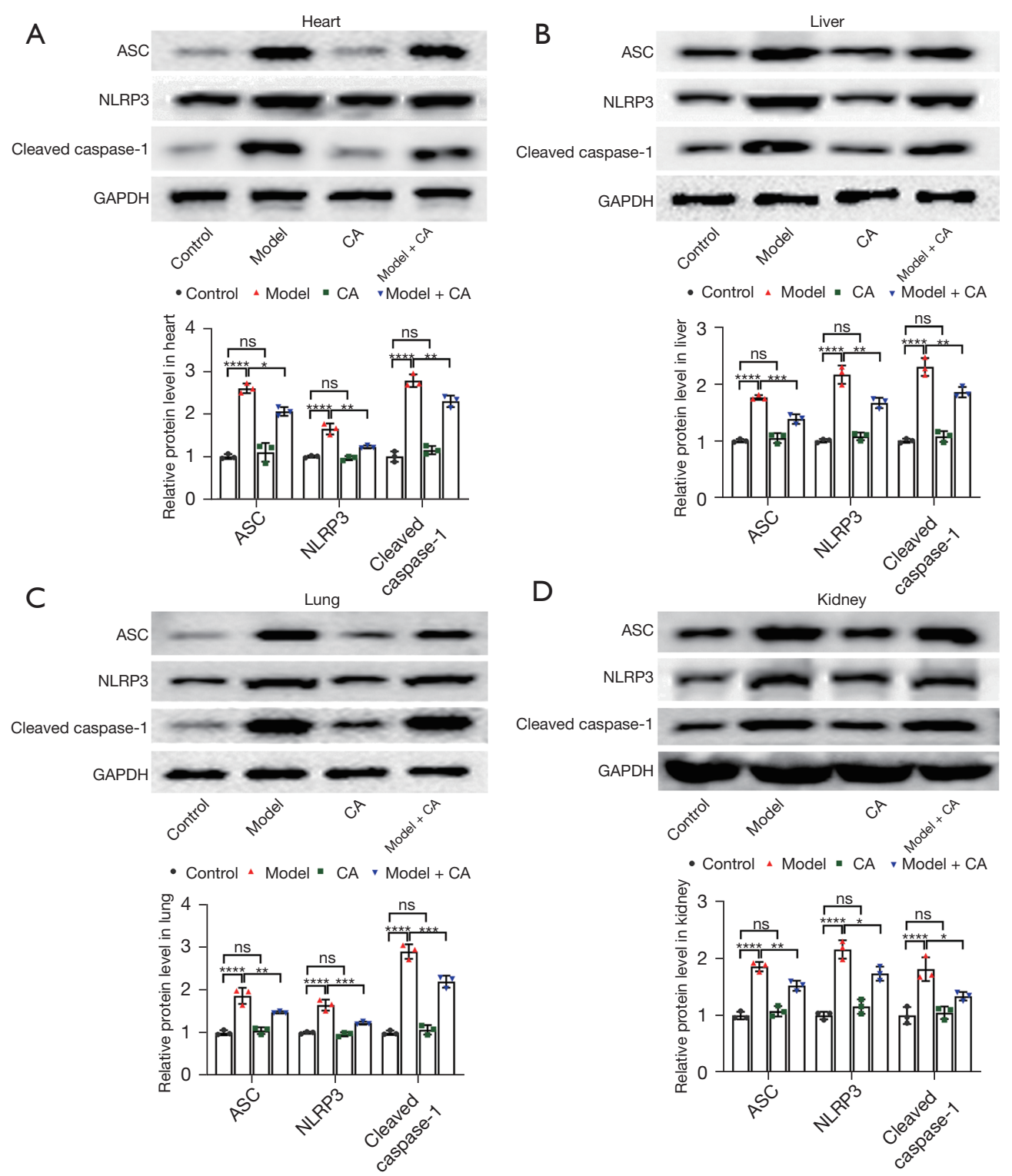

Figure 4 Western blot analysis showing the protein expression of ASC, NLRP3, and caspase-1 in the (A) heart, (B) liver, (C) lungs, and (D) kidneys. The relative expression level of the proteins is shown in the graphs. ${ }^{* * *}, \mathrm{P}<0.0001 ;{ }^{* * *}, \mathrm{P}<0.001 ;{ }^{* *}, \mathrm{P}<0.01 ;{ }^{*}, \mathrm{P}<0.05$. ns, not significant; CA, cinnamyl alcohol; ASC, apoptosis-associated speck-like protein containing a caspase recruitment domain; NLRP3, nucleotide-binding oligomerization domain-like receptor 3 .

for liver; $\mathrm{F}=49.64, \mathrm{P}<0.0001$ for heart; $\mathrm{F}=42.92, \mathrm{P}<0.0001$ for lungs; and $\mathrm{F}=70.56, \mathrm{P}<0.0001$ for kidneys), NLRP3 $(\mathrm{F}=88.73, \mathrm{P}<0.0001$ for liver; $\mathrm{F}=29.29, \mathrm{P}<0.0001$ for heart; $\mathrm{F}=57.16, \mathrm{P}<0.0001$ for lungs; and $\mathrm{F}=55.60, \mathrm{P}<0.0001$ for kidneys), and caspase-1 $(\mathrm{F}=109.40, \mathrm{P}<0.0001$ for liver; $\mathrm{F}=139.50, \mathrm{P}<0.0001$ for heart; $\mathrm{F}=159.70, \mathrm{P}<0.0001$ for lungs; and $\mathrm{F}=20.23, \mathrm{P}<0.001$ for kidneys) were significantly different among the 4 treatment groups, and the patterns of variation were similar in the liver, heart, lungs, and kidneys (Figure 4). The relative protein levels of ASC, NLRP3 and caspase-1 were significantly greater in the model group (mean \pm SD $=1.76 \pm 0.04$ for ASC, mean \pm SD $=2.16 \pm 0.16$ for NLRP3, and mean $\pm \mathrm{SD}=2.30 \pm 0.16$ for caspase- 1 in liver; mean $\pm \mathrm{SD}=2.60 \pm 0.11$ for ASC, mean \pm $\mathrm{SD}=1.78 \pm 0.03$ for $\mathrm{NLRP} 3$, and mean $\pm \mathrm{SD}=2.78 \pm 0.15$ for caspase- 1 in heart; mean $\pm \mathrm{SD}=1.86 \pm 0.19$ for ASC, mean \pm 
$\mathrm{SD}=1.65 \pm 0.13$ for $\mathrm{NLRP} 3$, and mean $\pm \mathrm{SD}=2.90 \pm 0.17$ for caspase-1 in lung; mean $\pm \mathrm{SD}=1.86 \pm 0.08$ for ASC, mean $\pm \mathrm{SD}=2.16 \pm 0.16$ for NLRP3, and mean $\pm \mathrm{SD}=1.81 \pm 0.20$ for caspase-1 in kidney) than those of model + CA group $($ mean $\pm \mathrm{SD}=1.38 \pm 0.08$ for ASC, mean $\pm \mathrm{SD}=1.66 \pm 0.09$ for $\mathrm{NLRP} 3$, and mean $\pm \mathrm{SD}=1.85 \pm 0.09$ for caspase- 1 in liver; mean \pm SD $=2.06 \pm 0.10$ for ASC, mean \pm SD $=1.35 \pm 0.06$ for NLRP3, and mean \pm SD $=2.29 \pm 0.14$ for caspase- 1 in heart; mean $\pm \mathrm{SD}=1.48 \pm 0.03$ for $\mathrm{ASC}$, mean $\pm \mathrm{SD}=1.23 \pm 0.04$ for $\mathrm{NLRP} 3$, and mean $\pm \mathrm{SD}=2.20 \pm 0.14$ for caspase-1 in lung; mean $\pm \mathrm{SD}=1.52 \pm 0.09$ for ASC, mean $\pm \mathrm{SD}=1.74 \pm 0.12$ for NLRP3, and mean $\pm \mathrm{SD}=1.34 \pm 0.08$ for caspase -1 in kidney). The protein levels of ASC, NLRP3, and caspase-1 was significantly greater in model + CA group than those of the control group (mean $\pm \mathrm{SD}=1.00 \pm 0.03$ for ASC, mean \pm $\mathrm{SD}=1.00 \pm 0.03$ for $\mathrm{NLRP} 3$, and mean $\pm \mathrm{SD}=1.00 \pm 0.04$ for caspase-1 in liver; mean $\pm \mathrm{SD}=1.00 \pm 0.27$ for ASC, mean $\pm \mathrm{SD}=1.00 \pm 0.17$ for NLRP3, and mean $\pm \mathrm{SD}=1.00 \pm 0.12$ for caspase- 1 in heart; mean $\pm \mathrm{SD}=1.00 \pm 0.07$ for ASC, mean $\pm \mathrm{SD}=1.00 \pm 0.03$ for NLRP3, and mean $\pm \mathrm{SD}$ $=1.00 \pm 0.05$ for caspase- 1 in lung; mean $\pm \mathrm{SD}=1.00 \pm 0.07$ for ASC, mean $\pm \mathrm{SD}=1.00 \pm 0.07$ for NLRP3, and mean $\pm \mathrm{SD}=1.00 \pm 0.15$ for caspase- 1 in kidney) and CA group $($ mean $\pm \mathrm{SD}=1.05 \pm 0.09$ for ASC, mean $\pm \mathrm{SD}=1.08 \pm 0.07$ for NLRP3, and mean $\pm \mathrm{SD}=1.07 \pm 0.09$ for caspase- 1 in liver; mean $\pm \mathrm{SD}=1.10 \pm 0.22$ for $\mathrm{ASC}$, mean $\pm \mathrm{SD}=1.06 \pm 0.13$ for NLRP3, and mean $\pm \mathrm{SD}=1.15 \pm 0.10$ for caspase- 1 in heart; mean $\pm \mathrm{SD}=1.05 \pm 0.08$ for ASC, mean $\pm \mathrm{SD}=0.96 \pm 0.05$ for $\mathrm{NLRP} 3$, and mean $\pm \mathrm{SD}=1.07 \pm 0.11$ for caspase-1 in lung; mean \pm SD $=1.08 \pm 0.09$ for ASC, mean \pm SD $=1.16 \pm 0.13$ for NLRP3, and mean $\pm \mathrm{SD}=1.05 \pm 0.11$ for caspase -1 in kidney), between which no difference was observed.

\section{Discussion}

The findings in this study suggested that sepsis induced by $E$. coli infection in the bloodstream leads to activation of the NLRP3 inflammasome pathway. The intracellular NLRs bind to caspase-1 via ASC, forming inflammasomes. Subsequently, caspase- 1 is activated due to recruitment of procaspase-1, resulting in the secretion of IL- $1 \beta$ and IL-8 (19). The secretion of IL-1 $\beta$ and IL-8 is associated with the pathogenesis of numerous acute and chronic inflammatory human diseases (20). Previous studies have reported that the NLRP3 inflammatory pathway is involved in the occurrence and development of immune diseases, including inflammatory bowel disease, multiple sclerosis, and metabolic disorders (21,22). Meanwhile, other reports have shown that activation of the NLRP3 inflammatory pathway benefits viral infections (22). Nonetheless, the important role of NLRP3 in bacterial infections remains to be fully understood. Zhong et al. (23) reported that NLRP3 signaling confers protection against polymicrobial abdominal infection but promotes lethality during disseminated bacterial infection. Zhu et al. (24) demonstrated that $E$. coli bloodstream infection is associated with the activation of the NLRP3 inflammatory pathway, and the expression of NLRP3 inflammasomes is related to the severity of the infection. While the current study suggested that cinnamyl alcohol reduced sepsis syndrome by inhibiting the NLRP3 inflammasome pathway, further investigations examining the clinical effects of cinnamyl alcohol are warranted.

\section{Acknowledgments}

We wish to thank our colleagues for their assistance in sampling.

Funding: This study was sponsored by Fujian Provincial Health Technology Project (2018-ZQN-41).

\section{Footnote}

Reporting Cbecklist: The authors have completed the ARRIVE reporting checklist. Available at https://atm. amegroups.com/article/view/10.21037/atm-21-6130/rc

Data Sharing Statement: Available at https://atm.amegroups. com/article/view/10.21037/atm-21-6130/dss

Conflicts of Interest: All authors have completed the ICMJE uniform disclosure form (available at https://atm. amegroups.com/article/view/10.21037/atm-21-6130/coif). The authors have no conflicts of interest to declare.

Ethical Statement: The authors are accountable for all aspects of the work in ensuring that questions related to the accuracy or integrity of any part of the work are appropriately investigated and resolved. Animal Experiments were granted by the ethics committee of Fujian Medical University (No. FJMU IACUC 2021-0512) and conformed to the Guide for the Care and Use of Laboratory Animals of the National Institute of Health for the care and use of animals.

Open Access Statement: This is an Open Access article 
distributed in accordance with the Creative Commons Attribution-NonCommercial-NoDerivs 4.0 International License (CC BY-NC-ND 4.0), which permits the noncommercial replication and distribution of the article with the strict proviso that no changes or edits are made and the original work is properly cited (including links to both the formal publication through the relevant DOI and the license). See: https://creativecommons.org/licenses/by-nc$\mathrm{nd} / 4.0 /$.

\section{References}

1. Bone RC, Balk RA, Cerra FB, et al. Definitions for sepsis and organ failure and guidelines for the use of innovative therapies in sepsis. The ACCP/SCCM Consensus Conference Committee. American College of Chest Physicians/Society of Critical Care Medicine. Chest 1992;101:1644-55.

2. Prasad PA, Fang MC, Abe-Jones Y, et al. Time to Recognition of Sepsis in the Emergency Department Using Electronic Health Record Data: A Comparative Analysis of Systemic Inflammatory Response Syndrome, Sequential Organ Failure Assessment, and Quick Sequential Organ Failure Assessment. Crit Care Med 2020;48:200-9.

3. Churpek MM, Snyder A, Sokol S, et al. Investigating the Impact of Different Suspicion of Infection Criteria on the Accuracy of Quick Sepsis-Related Organ Failure Assessment, Systemic Inflammatory Response Syndrome, and Early Warning Scores. Crit Care Med 2017;45:1805-12.

4. Shapiro L, Gelfand JA. Cytokines and sepsis: pathophysiology and therapy. New Horiz 1993;1:13-22.

5. Singer M, Deutschman CS, Seymour CW, et al. The Third International Consensus Definitions for Sepsis and Septic Shock (Sepsis-3). JAMA 2016;315:801-10.

6. Ayoola MB, Nakamya MF, Shack LA, et al. SP_0916 Is an Arginine Decarboxylase That Catalyzes the Synthesis of Agmatine, Which Is Critical for Capsule Biosynthesis in Streptococcus pneumoniae. Front Microbiol 2020;11:578533.

7. Cossart YE. The rise and fall of infectious diseases: Australian perspectives, 1914-2014. Med J Aust 2014;201:S11-4.

8. van der Poll T, van de Veerdonk FL, Scicluna BP, et al. The immunopathology of sepsis and potential therapeutic targets. Nat Rev Immunol 2017;17:407-20.

9. Takeuchi O, Akira S. Pattern recognition receptors and inflammation. Cell 2010;140:805-20.

10. Wang H, Vishnubhakat JM, Bloom O, et al. Proinflammatory cytokines (tumor necrosis factor and interleukin 1) stimulate release of high mobility group protein-1 by pituicytes. Surgery 1999;126:389-92 .

11. Deutschman CS, Tracey KJ. Sepsis: current dogma and new perspectives. Immunity 2014;40:463-75.

12. Arroyo DS, Soria JA, Gaviglio EA, et al. Toll-like receptors are key players in neurodegeneration. Int Immunopharmacol 2011;11:1415-21.

13. Shi $X$, Tan $S$, Tan S. NLRP3 inflammasome in sepsis (Review). Mol Med Rep 2021;24:514.

14. Cabello CM, Bair WB 3rd, Lamore SD, et al. The cinnamon-derived Michael acceptor cinnamic aldehyde impairs melanoma cell proliferation, invasiveness, and tumor growth. Free Radic Biol Med 2009;46:220-31.

15. Schink A, Naumoska K, Kitanovski Z, et al. Antiinflammatory effects of cinnamon extract and identification of active compounds influencing the TLR 2 and TLR4 signaling pathways. Food Funct 2018;9:5950-64.

16. Hwang DI, Won KJ, Kim DY, et al. Cinnamyl Alcohol, the Bioactive Component of Chestnut Flower Absolute, Inhibits Adipocyte Differentiation in 3T3-L1 Cells by Downregulating Adipogenic Transcription Factors. Am J Chin Med 2017;45:833-46.

17. Niklasson IB, Delaine T, Islam MN, et al. Cinnamyl alcohol oxidizes rapidly upon air exposure. Contact Dermatitis 2013;68:129-38.

18. Garofalo AM, Lorente-Ros M, Goncalvez G, et al. Histopathological changes of organ dysfunction in sepsis. Intensive Care Med Exp 2019;7:45.

19. Newton K, Dixit VM. Signaling in innate immunity and inflammation. Cold Spring Harb Perspect Biol 2012;4:a006049.

20. Shao BZ, Xu ZQ, Han BZ, et al. NLRP3 inflammasome and its inhibitors: a review. Front Pharmacol 2015;6:262.

21. Allen IC, Scull MA, Moore CB, et al. The NLRP3 inflammasome mediates in vivo innate immunity to influenza A virus through recognition of viral RNA. Immunity 2009;30:556-65.

22. Witzenrath M, Pache F, Lorenz D, et al. The NLRP3 inflammasome is differentially activated by pneumolysin variants and contributes to host defense in pneumococcal pneumonia. J Immunol 2011;187:434-40.

23. Zhong Y, Lu Y, Yang X, et al. The roles of NLRP3 inflammasome in bacterial infection. Mol Immunol 2020;122:80-8. 
24. Zhu M, Zhou S, Bao L. The role of NLRP3 inflammasome in immune response mechanism of Escherichia coli bloodstream infection. Acta Universitatis

Cite this article as: Zou L, Li C, Chen X, Yu F, Huang Q, Chen L, Wu W, Liu Q. The anti-inflammatory effects of cinnamyl alcohol on sepsis-induced mice via the NLRP3 inflammasome pathway. Ann Transl Med 2022;10(2):48. doi: 10.21037/atm-21-6130
Medicinalis Anhui 2018;1:75-8.

(English Language Editor: J. Teoh) 